\title{
Defective insulin receptor tyrosine kinase in human skeletal muscle in obesity and Type 2 (non-insulin-dependent) diabetes mellitus
}

\author{
P.Arner ${ }^{1}$, T. Pollare ${ }^{2}$, H. Lithell ${ }^{2}$ and J. N. Livingston ${ }^{3}$ \\ ${ }^{1}$ Department of Medicine, Karolinska Institute, and the Research Centre at Huddinge Hospital, Stockholm, and \\ ${ }^{2}$ Department of Geriatrics, Uppsala University, and the Kungsgärdet's Hospital, Uppsala, Sweden; \\ ${ }^{3}$ Department of Medicine, University of Rochester, School of Medicine and Dentistry, Rochester, New York, USA
}

Summary. The tyrosine kinase activity of the insulin receptor was investigated in skeletal muscle biopsies from insulin-resistant males with obesity or with Type 2 (non-insulin-dependent) diabetic males who were lean or overweight. The kinase activity of the receptor from all three groups of insulin-resistant subjects was $40 \%$ less when compared to the activity of lean control subjects. This alteration was present in the absence of changes in the level of the insulin receptor on its insulin binding characteristics. We conclude that the tyrosine kinase activity of the skeletal muscle insulin receptor is defective in obesity and Type 2 diabetes, and that this alteration contributes to the insulin-resistant characteristics of both disorders.

Key words: Glucose, insulin, receptor, metabolism.
Resistance to insulin is a common feature of obesity and Type 2 (non-insulin-dependent) diabetes. The cause of the resistance in skeletal muscle, a major insulin target organ, has not been identified; but events following receptor binding of insulin have been implicated [1]. Stimulation of the receptor-associated tyrosine kinase activity is the earliest recognised event after insulin binds to the receptor [1]. We therefore examined the activity of the insulin receptor tyrosine kinase in human muscle in these insulin-resistant states. Sixtyyear-old male patients with Type 2 diabetes who were lean or overweight and lean and obese non-diabetic subjects were investigated.

\section{Subjects and methods}

\section{Subjects}

All subjects were males between $60-70$ years of age, who participated in a health screening study in Uppsala, a middle-sized town in Sweden [2]. The subjects were drug-free and healthy except for obesity and Type 2 diabetes in affected individuals. The diabetic patients were divided into two groups, non-obese patients and patients who were overweight. Diabetes was diagnosed during the health screening procedure: in these patients, fasting blood glucose was moderately elevated but urinary glucose and ketones were absent. After an overnight fast, plasma glucose, plasma insulin, intravenous glucose tolerance, and body mass index were determined as described [2] in 7 non-obese healthy subjects, 20 moderately obese non-diabetic subjects, 8 moderately obese Type 2 diabetic patients, and 8 non-obese
Type 2 diabetic patients. On a separate day after an overnight fast, two or three muscle biopsies (200-300 mg total wet weight) were taken from the left vastus lateralis muscle. The biopsies were immediately frozen in liquid $\mathrm{N}_{2}$ and maintained in $\mathrm{N}_{2}$ until used for the receptor studies. For ethical reasons it was not possible to obtain larger quantities of muscle from each donor. All subjects consumed a similar diet $(10.5 \mathrm{MJ} / 24 \mathrm{~h})$ that consisted of $35 \%$ fat, $48 \%$ carbohydrate, $15 \%$ protein and $2 \%$ alcohol according to dietary history [2].

\section{Insulin binding to muscle insulin receptors}

The frozen muscle biopsies were extracted at $4^{\circ} \mathrm{C}$ with $5 \mathrm{ml}$ of Tris buffer, $\mathrm{pH} 7.4$ that contained $1 \%$ Triton X-100. $5 \mathrm{mmol} / \mathrm{l}$ (ortho) vanadate, $2 \mathrm{mmol} / 1$ p-nitrophenyl phosphate, $1 \mathrm{mmol} / 1$ phenylmethylsulfonyl fluoride (PMSF), $100 \mathrm{mmol} / 1 \mathrm{NaF}, 5 \mathrm{mmol} / 1$ EDTA, and $1 \mathrm{mg} / \mathrm{ml}$ bacitracin. Following a $30 \mathrm{~min}$ extraction period, $15 \mathrm{ml}$ of this buffer minus Triton X-100 was added and the insoluble material removed by centrifugation $(30,000 \mathrm{~g}$ for $30 \mathrm{~min})$. The supernate was subjected to membrane filtration (Metricle filter GA-6, $0.45 \mu \mathrm{m}$ ) and the filtrate was cycled three times over a $1 \mathrm{ml}$ wheat germ agglutin affinity column [3]. The column was washed overnight with a $50 \mathrm{mmol} / 1$ Tris buffer, $\mathrm{pH} 7.4$, that contained $0.5 \mathrm{~mol} / 1 \mathrm{NaCl}$, $1 \mathrm{mmol} / 1 \mathrm{PMSF}$, and $0.1 \%$ Triton $\mathrm{X}-100$. The column was subjected to centrifugation $(800 \mathrm{~g}$ for $30 \mathrm{~s}$ ) to remove the remaining wash buf-

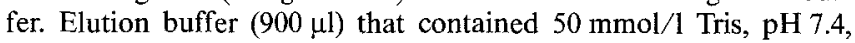
$0.1 \%$ Triton $\mathrm{X}-100,1 \mathrm{~mol} / 1 \mathrm{NaCl}$, and $0.3 \mathrm{~mol} / 1 \mathrm{n}$-acetylglucosamine was mixed with the "dried" column material. After $1 \mathrm{~h}$ the eluate that contained the insulin receptor was collected by repeating the centrifugation step. The recovery with this procedure was $35 \% \pm$ $0.5 \%$ (mean $\pm \mathrm{SEM}$ ) in 6 separate experiments. Insulin binding activity was measured in a $50 \mu$ assay using a tracer ${ }^{125} \mathrm{I}$-insulin (A-14) of $50 \mathrm{~mol} / 1$ and various concentrations of native insulin in a $50 \mathrm{mmol} / \mathrm{l}$ Tris buffer, $\mathrm{pH} 7.6$ that contained $0.1 \%$ Triton-X-100, $0.1 \%$ bovine albumine and $1 \mathrm{mg} / \mathrm{ml}$ bacitracin. Non-specific insulin binding was 
Table 1. Clinical data for the human subjects

\begin{tabular}{|c|c|c|c|c|c|}
\hline & $\begin{array}{l}\text { Number of } \\
\text { subjects }\end{array}$ & $\begin{array}{l}\text { Body mass } \\
\text { index }\end{array}$ & $\begin{array}{l}\text { Intravenous glucose } \\
\text { tolerance } \\
\text { (\% per min) }\end{array}$ & $\begin{array}{l}\text { Plasma glucose } \\
(\mathrm{mmol} / \mathrm{l})\end{array}$ & $\begin{array}{l}\text { Plasma } \\
\text { insulin } \\
(\mathrm{mU} / \mathrm{l})\end{array}$ \\
\hline Moderately obese control subjects & 20 & $31.1 \pm 0.9^{b}$ & $1.16 \pm 0.07^{\mathrm{a}}$ & $5.0 \pm 0.1$ & $13.6 \pm 1.8^{\mathrm{a}}$ \\
\hline Moderately obese Type 2 diabetic patients & 8 & $30.3 \pm 0.8^{b}$ & $0.47 \pm 0.03^{\mathrm{b}}$ & $7.5 \pm 0.5^{\mathrm{b}}$ & $14.7 \pm 1.4^{b}$ \\
\hline
\end{tabular}

The data are the mean \pm SE. Statistical difference between control and study groups were determined by Student's unpaired t-test. ${ }^{a}=p>0.01$; $\mathrm{b}=p<0.001$
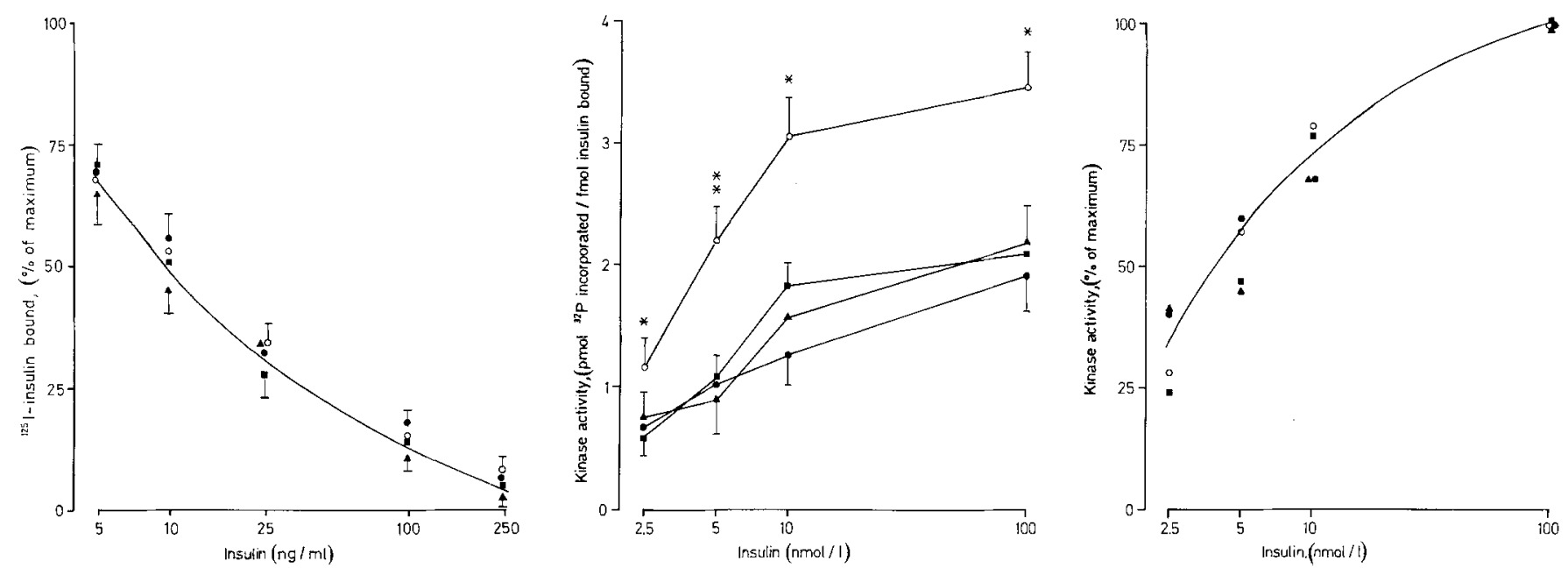

Fig. 1. Insulin receptor binding and insulin receptor tyrosine kinase activity in human muscle. A partially purified insulin receptor preparation was obtained by using wheat germ agglutinin affinity column chromatography. Insulin binding activity was measured using a tracer ${ }^{125}$ I-insulin (A-14) of $50 \mathrm{pmol} / 1$ and the indicated concentration of native insulin. Specific insulin binding was determined. The results of competition-inhibition experiments with radioactive and cold insulin are depicted in the left graph were 100\% represents the specific binding found with the tracer ${ }^{125} \mathrm{I}$-insulin concentration. The $\mathrm{B} / \mathrm{F}$ values per $\mu \mathrm{g}$ protein (mean $\pm \mathrm{SE}$ ) for the four groups at the tracer hormone concentration were: control subjects $=0.048 \pm 0.016$; obese control subjects $=0.046 \pm 0.006$; obese Type 2 diabetic patients $=0.042 \pm 0.015$; and non-obese Type 2 diabetic patients $=0.054 \pm 0.012$. The tyrosine kinase activity was measured under conditions described in the text, using the artifical substrate, poly-Glu ${ }^{80} \mathrm{Tyr}^{20}$, insulin at the indicated concentration and the wheat germ agglutinin extract described above which contained the partially purified insulin receptor preparation. The middle panel illustrates the insulin-stimulated kinase activity expressed per insulin binding measured with $50 \mathrm{pmol} / \mathrm{L}^{125} \mathrm{I}$-insulin (mean $\pm \mathrm{SEM}$ ). The right panel illustrates the insulin dose-response curve when maximum stimulation (100 nmol/1 insulin) for each group was set at $100 \%$. The symbols used and the number of subjects included are defined in the figure. Statistical significance was determined by analysis of variance. ${ }^{*}=p<0.05 ;{ }^{*}=p<0.01$. $\bigcirc$ Non-obese control subjects, $n=7$; non-obese Type 2 diabetic patients, $n=8 ; \boldsymbol{\square}$ obese control subjects, $n=20 ; \boldsymbol{\Delta}$ obese Type 2 diabetic patients, $n=8$

determined as the amount bound in the presence of $5 \mu \mathrm{g} / \mathrm{ml}$ insulin. After a $16-\mathrm{h}$ incubation at $4{ }^{\circ} \mathrm{C}$, the assay was terminated by the polyethylene glycol precipitation method as described previously [4]. Insulin degradation was less than $10 \%$ of the tracer hormone added and non-specific binding was approximately $9 \%$ of total tracer binding. The binding data were expressed as bound versus free $(B / F)$ and normalised for the amount of protein in the assay. The latter was determined as described previously [7].

\section{Tyrosine kinase activity of the insulin receptor from human muscle}

The tyrosine kinase activity was measured exactly under conditions previously described [5], using the artifical substrate, poly-Glu ${ }^{80} \mathrm{Tyr}^{20}$. In these assays, insulin at various concentrations was pre-incubated with $20 \mu \mathrm{l}$ of the wheat germ agglutinin extract at $24^{\circ} \mathrm{C}$ for $30 \mathrm{~min}$. The tyrosine kinase activity was then measured during a 20 -min incubation at $24^{\circ} \mathrm{C}$. Termination of the assay and measurement of the amount of phosphorylated substrate were conducted as reported [5].

This assay was used to measure the kinase activity because of its sensitivity and because receptor autophosphorylation, the other method of measuring kinase activity, has uncertainties inherent in the interpretation of the results [4]. The results of the kinase experiments were expressed on the basis of insulin binding, and the basal activity (i. e., activity in the absence of insulin stimulation) was substracted from the insulin-stimulated activity.

The tyrosine kinase activity under these conditions was directly proportional to the amount of extract added and to the time period of incubation. We also examined whether any excessive destruction of ATP occurred during the incubation. ATP was separated from other nucleotides and inorganic phosphate by the method of Bochner and Ames [6]. The amount of radiolabelled ATP before and after a 20-min incubation with the wheat-germ agglutinin extract was essentially the same. This speaks against significant ATP degradation during the incubation. The tyrosine kinase activity was expressed per amount of insulin bound at tracer hormone concentration.

\section{Statistical analysis}

Data are presented as the mean $\pm S E M$. The two tailed Student's t-test and analysis of variance were employed for statistical analysis. 


\section{Results}

Table 1 illustrates the pertinent clinical information for the individuals examined in this study. The subjects in the obese diabetic or non-diabetic groups were approximately $20 \%$ overweight. Insulin resistance in the obese and diabetic groups was documented by a 2 to 3 -fold elevation in fasting insulin levels and by a $40-80 \%$ decrease in intravenous glucose tolerance. The mean age was 64 years in all groups.

Insulin binding studies demonstrated a similar content of insulin receptors in the muscle extracts from the obese and diabetic groups as that found for the lean control subjects (Fig.1, left panel). The values for the $\mathrm{B} / \mathrm{F}$ ratio per $\mu \mathrm{g}$ of protein were similar among the four groups at all concentrations of insulin used in the binding studies. At tracer ${ }^{125}$ I-insulin, this ratio was in the range of $0.05 \mu \mathrm{g}$ protein (exact values are given in the legend to Figure 1). Also, the binding affinity was similar in all groups as determined by the results from the insulin competition experiments. Fifty percent displacement of tracer insulin was produced by approximately $10 \mathrm{ng} / \mathrm{ml}$ native insulin in the receptor preparations from the four groups.

Insulin-stimulated tyrosine kinase activity for all three insulin resistant states was significantly less than the activity found in the receptors from the lean control subjects (Fig.1, middle panel). This alteration was present for each concentration of insulin used to stimulate the tyrosine kinase activity. With maximum insulin stimulation, the tyrosine kinase activity for the three groups of insulin-resistant subjects was approximately $40 \%$ less than the control activity. No significant differences were found, however, among the three resistant groups; all had approximately the same degree of reduction. The insulin dose-response characteristics for the activation of the receptor kinase was similar for the four groups (Fig.1, right panel). The half-maximum effect occurred at approximately $4 \mathrm{nmol} / \mathrm{l}$ of insulin. The basal activity did not differ significantly between the groups. These activities (pmol phosphate incorporated/fmol of insulin binding) for the groups were: Non-obese control subjects $=1.04 \pm 0.21$; obese control subjects $=1.02 \pm 0.11$; obese diabetic patients $=0.87 \pm$ 0.1 ; and non-obese diabetic patients $=1.08 \pm 0.13$.

\section{Discussion}

The present study shows normal insulin binding, but inhibited insulin-induced receptor tyrosine kinase activity in human muscle in the two most common forms of insulin resistance - obesity and Type 2 diabetes. Furthermore, the decrease in enzyme activity was in the same order of magnitude in both conditions (about $40 \%$ ) and the combination of the two disorders did not produce any additional changes. These observations were made in a very homogenous group of 60-year-old men. It is therefore not known if women or younger subjects show other or similar changes in insulin action in obesity and Type 2 diabetes.

Insulin resistance at the target cellular level may be caused by several events, the earliest being an alteration in the receptor [1]. The insulin dose-response characteristics for the activation of the receptor kinase were similar for control and study groups. Therefore, the coupling between the insulin binding site of the receptor and the catalytic subunit remained intact in receptors that could respond to insulin by an increase in kinase activity.

The lack of an alteration in insulin binding argues against a change in the number of insulin receptors in the muscle of the insulin-resistant subjects. This interpretation must be tempered somewhat since the small amount of tissue available for the present study required detergent extraction rather than the use of isolated membranes. Thus, we cannot comment on the number of receptors available to bind inulin in the intact tissue. However, it is unlikely that a large reduction in "active" receptors exists in these subjects unless the distribution between intracellular and cell surface receptors was markedly altered.

While the present study reports on the muscle insulin receptor in obesity and diabetes, other studies have examined the insulin receptor in the liver of subjects affected with both disorders. For example, insulin binding by liver membranes of extremely obese subjects with and without diabetes is reduced [7, 8], whereas binding is increased in normal weight Type 2 diabetic patients [9]. Thus, the tissue examined and the degree of obesity evidently influences the level of the insulin receptor. However, it is evident from our results that moderate obesity in the presence or absence of Type 2 diabetes does not result in an overall loss of insulin receptors in muscle. Because of the limited amount of muscle tissue that was available it was not possible to investigate the molecular structure of the insulin receptor in the present study.

Although we cannot relate the insulin resistance in muscle to loss of insulin receptors, the alteration found in the tyrosine kinase from these patients suggests an underlying cause, i.e., an alteration in the signalling property of the receptor. Insulin stimulation of glucose transport in muscle tissue plays a major role in glucose disposal [1]. If there is a role for the tyrosine kinase activity in the stimulation of glucose transport [1] the $40 \%$ reduction in this activity observed in all three groups should alter the insulin response of affected muscle tissue and contribute to the overall in vivo insulin resistance in glucose utilisation.

The reduction in the kinase activity of muscle receptors in the absence of an insulin binding or coupling alteration suggests that some receptors have lost their phosphotransferase capability. Furthermore, insulin-stimulated tyrosine kinase activity can be modulated apparently by receptor phosphorylation and de- 
phosphorylation reactions [1]. These abnormalities offer an explanation for how a kinase defect can develop, although little is known of the actual molecular events that underlie such changes. For example, the ATP-dependency of insulin receptor tyrosine kinase might be altered in obesity and Type 2 diabetes mellitus. Unfortunately, it was not possible to investigate the kinetic properties of ATP-dependency for the tyrosine kinase in this study because the methods require much larger amounts of muscle tissue than was possible to obtain from each donor.

Similarly, the inciting cause of the impaired kinase activity is not known: however, the elevated insulin levels in the insulin-resistant subjects may contribute to its development. All three groups of insulin-resistant subjects had the same degree of hyperinsulinaemia and the same degree of reduction in tyrosine kinase activity. This correlation between hyperinsulinaemia and kinase activity agrees with prior studies of rat adipocytes [4] which demonstrated a $30-40 \%$ reduction in the tyrosine kinase activity of the insulin receptor.

As regards previous human studies, insulin receptor tyrosine kinase activity in obesity and Type 2 diabetes has recently been characterised in adipose tissue and liver. A decrease in the kinase activity of the insulin receptor has been reported in subcutaneous tissue of Type 2 diabetic patients [10]. A specific defect in the kinase activity of the hepatic insulin receptor from obese diabetic patients was found, although in contrast to the present results, no kinase alteration was evident in obese non-diabetic subjects [8]. As discussed for insulin binding, the latter difference may relate to the different tissue studied and the difference in the degree of obesity.

In summary, we conclude that the alteration in the tyrosine kinase activity is the major receptor-associated defect in muscle from obese and Type 2 diabetic patients. Because skeletal muscle is the tissue primarily responsible for insulin-stimulated disposal of glucose, the intrinsic kinase alteration rather than a loss of receptors likely accounts for the decreased glucose tolerance and insulin-resistance present in both metabolic disorders.
Acknowledgements. This study was supported by the Swedish Medical Research Council (Grants 1034 and 5446), The Swedish Diabetes Association, The Foundations of Nordic Insulin, Folksam and Throne-Holst, and NIH grant AM20129.

\section{References}

1. Kahn CR (1985) The molecular mechanism of insulin action. Ann Rev Med 36: 429-451

2. Bolinder J, Lithell H, Skarfors E, Arner P (1986) Effects of obesity, hyperinsulinemia and glucose intolerance on insulin action in adipose tissue of sixty-year-old men. Diabetes 35: 282-290

3. Harrison LC, Itin AJ (1980) Purification of the insulin receptor from human placenta by chromatography on immobilized wheat germ lectin and receptor antibody. J Biol Chem 255: 12066-12072

4. Arsenis G, Livingston JN (1986) Alterations in the thyrosine kinase activity of the insulin receptor produced by in vivo hyperinsulinemia. J Biol Chem 261: 147-153

5. Braun S, Raymond WE, Racker EJ (1984) Synthetic thyrosine polymers as substrates and inhibitors of thyrosine-specific protein kinase. J Biol Chem 259: 2051-2054

6. Bochner BR, Ames BN (1982) Complete analysis of cellular nucleotides by two-dimensional thin layer chromatography. J Biol Chem 257: 9759-9769

7. Arner P, Einarsson K, Backman L, Nilsell K, Lerea KM, Livingston JN (1983) Studies of liver insulin receptor in non-obese and obese human subjects. J Clin Invest 72: 1729-1736

8. Caro J, Ittopp O, Poris WJ, Meelhem D, Flickinger EG, Thomas F, Jenquin M, Silverman JF, Khazanie PG, Sinha MK (1986) Studies of the mechanisms of insulin resistance in the liver from humans with non-insulin dependent diabetes. J Clin Invest 78: $249-258$

9. Arner P, Einarsson K, Ewerth S, Livingston JN (1986) Studies of the human liver insulin receptor in non-insulin-dependent diabetes mellitus. J Clin Invest 77: 1716-1718

10. Freidenberg GR, Henry RR, Klein HH, Reichard DR, Olefsky JM (1987) Decreased kinase activity of insulin receptors from adipocytes of non-insulin-dependent diabetic subjects. J Clin Invest $79: 240-250$

Received: 29 April 1987

Dr. Peter Arner

Department of Medicine

Huddinge Hospital

S-14186 Huddinge

Sweden 